\title{
THE EFFECT OF SEPARATION OF INITIAL ASSESSMENT DOCUMENTS ON THE LENGTH OF STAY IN EMERGENCY INSTALLATION IN KENDARI CITY GENERAL HOSPITAL
}

\author{
Tono Sumanto $^{1}$, Sunarsih ${ }^{2}$, Timbul Supodo ${ }^{3}$ \\ ${ }^{1,2,3}$ Master of Public Health Study Program, Universitas Mandala Waluya, \\ Kendari, Southeast Sulawesi, Indonesia
}

Corresponding Author: Tono Sumanto

E-mail: tonzhusumanto@gmail.com

\section{Abstract}

Background: A preliminary survey of prospective researchers in the Kendari City General Hospital especially in the Emergency Installation (ER), the number of emergency room visits has decreased in the last 3 years, in 2017 the total number of patients treated in the ER was 10.869 patients, then in 2018 the number of visits decreased to 10.768 patients, and in 2019 the number of visits fell to 9.747 patients. Meanwhile, based on the data in the last few months in 2020 there was a very large spike in decline in the last month, in January 2020 the number of patient who visited, were 849 people, then in February 2020 the number of the patient were 1202 patients, March 2020 the number of visits was 1216 patients and finally in April 2020 it fell to 451 people. The purpose of this study is to analyse the effect of separation of the initial assessment documents on Length of Stay in Emergency Installation in Kendari City General Hospital.

Methods: The research design was experimental with design pretest post-test one group design. The research location was in the Emergency Room of the Kendari City Regional General Hospital which was carried out during February 2021. The population of all patients who were hospitalized was $>17$ years old while the sample was 18 people with the sampling technique of separated random sampling.

Result: This study found separation of the initial assessment documents affected significantly to Length of Stay patients in Emergency room in Kendari City General Hospital (p- value = $0.045<0.05)$.

Conclusion: Separation technique of the initial assessment documents on Length of Stay was effective to reduce the Length of Stay patients in Emergency room in Kendari City Hospital.

Key words: Initial, Assessment, Documents, Length of Stay

Indonesian Journal Of Health Sciences Research and Development 


\section{INTRODUCTION}

The main health services in Indonesia that are able to provide curative, preventive and outpatient services and inpatient services as a whole are part of a health service arrangement by the hospital. Education and training facilities for health workers and research are also part of a hospital's function (1). Hospitals are health services that require good management and service systems to develop into quality institutions(2).

To meet the demands and needs of customers who want solutions to their health problems and receive services from health workers in an effort to find healing and recover from the pain they suffer is the main task of the hospital. Customers always want services that are ready, responsive, comfortable and fast are things that are always chill by the patient. In an effort to fulfill the demands of the patient, the main thing is excellent service by the hospital (3).So it takes a lot of energy in efforts to change people's behavior in line with the health development program (4).

Excellent service is the most important element in a hospital that is always asked to provide services especially in public health that are able to provide optimal health service standards so that in the future, service to patients can increase in the globalization era(5).

Length of Stay (LOS) in the ER is usually used to monitor the density status and length of service for all patients in the ER, which are calculated from the time the patient arrives until the time the patient leaves the ER (6). Length of Stay (LOS) is also an effective measuring tool for assessing the performance of an Emergency Room and the quality of the ER, the total Length of Stay (LOS) consists of arrival service times, laboratory examination service times, radiology examination service times and availability of beds in other inpatient rooms (7).

The accuracy and speed of safety efforts made to patients who enter the emergency room requires standards that are adjusted to the capabilities and competencies of health workers, so that later they are able to be responsible for proper and fast emergency handling efforts. By improving human resources, emergency service management, as well as facilities and infrastructure in accordance with this standard can be achieved (8).

The process of admission to patients in the Emergency Room focuses on the stages of patient entry and the achievement of targets at predetermined times. The Emergency Model of Caretermining targets in the throughput stage only takes four hours, and divides them into three time frames. In the first time frame, the throughput process is set at 2 hours, calculated from the time the patient enters the ER (registration), then triage or sorting the patient based on the patient's acuity level, then an assessment is carried out by health workers in the ER, namely the initial examination and supporting diagnostics and a management plan. clinical. The second time frame flow in the throughput is set at 1 hour whose activities are reviews by a team of specialists, consultation and disposition by doctors for later determination of admission to hospitalization, discharge, nor any other action. The third time flow of the throughput for 1 hour is the time to wait for the patient to be discharged from the ER for referral, discharge, or hospitalization.(9)

\section{METHOD}

The research design was experimental with designpre test post test one group design.The research location was in the Emergency Room of the Kendari City Regional General Hospital which was carried out during February 2021. The population of all patients who were hospitalized was $>17$ years old while the sample was 18 people with the sampling technique of separated random sampling. Then it can be determined that 9 samples will be separated from the initial assessment documents and 9 samples that will continue to follow the existing and current procedures in the emergency 
Sumanto, T., Sunarsih, and T. Supodo.

DOI: 10.36566/ijhsrd/Vol3.Iss2/83

https://ijhsrd.com/index.php/ijhsrd

e- ISSN: 2715-4718

departments Regional General Hospital Kendari City

RESULT

Table 1 shows that based on Length of Stay in phase 1 time frame model, there are 14 patients / respondents $(77.8 \%)$ that can be completed in less than 2 hours, while as many as 4 patients / respondents (22.2\%)

take more than 2 hours to be able to complete phase 1 of the time frame model.

Table 2 shows that there is an effect of separation of the initial assessment document on Length of Stay. This can be seen from the number sig. (2-tailed) that is smaller than 0.05 , that is, with a value of 0.045 .

Respondents' Length of Stay

\begin{tabular}{c|c|c}
\hline $\begin{array}{c}\text { Phase 1 Time } \\
\text { Frame Model }\end{array}$ & $\mathbf{f}$ & $\boldsymbol{\%}$ \\
\hline$<2$ hours & 14 & 77.8 \\
\hline$>2$ Hours & 4 & 22.2 \\
\hline Total & $\mathbf{1 8}$ & $\mathbf{1 0 0}$ \\
\hline
\end{tabular}

Table 2

Results of Independent t-Test Analysis The Effect of Separation of Initial Assessment Documents on Length of Stay (LOS)

\begin{tabular}{|c|c|}
\hline \multirow{2}{*}{$\begin{array}{l}\text { Length } \\
\text { of Stay } \\
\text { phase } \\
1\end{array}$} & Equal variances assumed \\
\hline & $\begin{array}{l}\text { Equal variances not } \\
\text { assumed }\end{array}$ \\
\hline
\end{tabular}

The Effect of Separation of Initial Assessment Documents on Length of Stay (LOS) in the Emergency Room at the Kendari City Regional General Hospital

Assessment documentInitial are several documents from the Medical Record (RM) bundle which consists of the Emergency Patient Initial Medical Assessment, the DPJP Determination Form, the Emergency Emergency Nursing Study and the Emergency Patient Observation Sheet (10). In normal conditions, the emergency services at the Kendari City Regional General Regional General Hospital 1 are an integral part of 79 other documents which are entirely in the Medical Record sheet which cannot be separated, this often hinders t-test for Equality of Means

\begin{tabular}{r|r|r}
\hline df & $\begin{array}{r}\text { Sig. (2- } \\
\text { tailed) }\end{array}$ & \multicolumn{1}{c}{$\begin{array}{c}\text { Mean } \\
\text { Difference }\end{array}$} \\
16 & .045 & .400 \\
\hline 9,000 & .037 & .400 \\
\hline
\end{tabular}

the flow of patient care because this initial assessment document is on the order of 13 , 14,15 and 19 in the emergency medical record bundle of Kendari City Regional General Hospital 1 as a whole which must be run sequentially according to the numbering of the documents given, and resulted in the initial assessment being unable to continue before filling in the first document until the 12 th medic record document was completed.

In this study, the 4 initial assessment sheets were separated from the medical record sheet, so that the initial assessment process for the patient could coincide with other documents on the medical record sheet, especially the patient administration process which was generally in the initial document on the medical record sheet. So that in its application, this process is expected to be 
able to cut the length of stay of patients in the ER at the Kendari City Regional General Hospital.

Length of Stayis the time lag between patients when they are in the room, area, installation, department, or special unit in a hospital until they move to another place, in an Emergency Room service condition, LOS is defined as the length of time the patient is in the Emergency Room, starting when list up to physically leave the patient from the Emergency Room(11).

Emergency Model Of Care divides the stages of patient throughput in the Emergency Department into three time frames or phases (the 2: 1: 1 time frame model), including: the initial stage to complete the initial assessment and clinical management planning which usually takes two hours. The second stage is a review by a specialist team or a consultation then a position with a prediction of one hour. the final stage, namely the transfer of patients, whether referring, going home or to the inpatient unit is also predicted to be completed in one hour.

This study does not look at Length of Stay as a whole, but only focuses on the first phase in the time frame model, which is the initial stage for completing the initial assessment and clinical management planning which generally takes two hours, this is because in phase 2 , namely a review by a specialist team, an assessment process. the beginning has been completed so it does not have a lag effect on service time to patients.

Based on the results of the Independent Sample t-Test statistical test, it can be concluded that there is an effect of separation of the initial assessment documents on Length of Stay. This can be seen from the number sig. (2-tailed) that is smaller than 0.05 , that is, with a value of 0.045 .

The results of this study indicate that the separation of the initial assessment documents does have an overall effect on the phase 1 time frame model which has an impact on the cut in the length of stay of patients in the ER. Several officers at the IGD Kendari City Regional General Hospital also admitted that this separation made the service time for patients cut by up to $50 \%$ of the time in general, which is usually up to 120 minutes of service, can be cut up to 60 minutes.

This research is in line with the results of research conducted by(7), who argued that the assessment time had an effect on the length of stay of patients in the emergency room. This fact was in line with the research conducted by Bukhari and colleagues in 2014. They re-evaluated the LOS of patients in the ER and the factors that influence it, and found that LOS was associated with arrival time, triage level, consultation time, laboratory examination time, radiological examination time and physical disposition time (waiting time for transfer to an inpatient bed), with the concept of time frame guide emergency model of care, where in this concept it states that phase 1 time The IGD assessment model or time frame is the dominant one, consuming half the IGD LOS targeted.

The results of the observation of a total of 18 visits in the phase 1 time frame model showed that the average time needed for the initial assessment was 112 minutes for patients whose initial assessment sheet was not separated from the medic record bundle with the fastest time being 60 minutes and the longest time 192 minutes, while for patients the initial assessment sheet was not separated from the medic record bundle. The assessment sheet initially separated from the medic record bundle only had an average of 43 minutes to go through the phase 1 time frame model with the longest time was 90 minutes and the fastest was only 15 minutes.

The facts above show that in general, the separation of the initial assessment documents makes the service time in phase 1 of the time frame model more efficient which allows a reduction in the length of stay of patients in the ER at the Kendari City Regional General Hospital, if dividing the overall model time frame which is usually $2: 1: 1$ 
with a total of 4 hours, the time can be shortened to 1: 1: 1 with a total of only 3 hours. If the LOS target is set to follow the 4-hour Emergency model of care, then this target has generally been met.

Researchers assume that if the research becomes the standard application used by the IGD of the Kendari City Regional General Hospital, namely separating the initial assessment document from the Medical Record bundle, it will be able to improve the quality of service in the ER in a timely manner, so that in the future the Regional General Hospital is sufficient to modify the second and third phase services in The time frame model which is also possible can narrow the service time in the ER, so that the total Length of Stay of patients in the ER can be shorter, which is likely to have an impact on increasing patient acceptance quantitatively with the speed of service, because the faster a service will also have an impact on the higher number of patients served.

\section{CONCLUSION}

There is an effect of separation of the initial assessment documents on Length of Stay so as to shorten the Length of Stay in the Emergency Room at the Kendari City Regional General Hospitall. Then the system for separating the initial assessment document from the medical record bundle can be applied in a standard manner by the Kendari City Regional Regional General Hospital management so that it can be used by the IGD section of the Kendari City Regional General Hospital.

\section{REFERENCES}

1. Lubis MFS, SImanjorang A. Faktor Yang Memengaruhi Kejadian Pulang Atas Permintaan Sendiri (PAPS) Pada Pasien Rawat Inap di RSU Madani Kota Medan. Jurnal Rekam Medic. 2018;1(2):53-63.

2. Akbar MI. Survey Tingkat Kepuasan Pasien Rawat Jalan Terhadap Pelayanan RSUD Kabupaten Buton
Utara. Jurnal Kesehatan Masyarakat Celebes. 2020;1(04):1-8.

3. Lestari Y, Nurcahyanto H. Analisis Tingkat Kepuasan Pasien Rawat Jalan (Studi Kasus Pada Pasien Rawat Jalan Di RSUD Dr. M. Ashari Kabupaten Pemalang). Journal of Public Policy and Management Review. 2017;6(2):441-54.

4. Jayadipraja EA, Prasetya F, Azlimin A, Mando WOSY. Family clean and healthy living behavior and its determinant factors in the village of Labunia, Regency of Muna, Southeast Sulawesi Province of Indonesia. Public Health of Indonesia. 2018;4(1):39-45.

5. PUSPANINGTYAS V, Supriadi O, Waseh H. MANAJEMEN PELAYANAN KESEHATAN JIWA ANAK DAN REMAJA OLEH DINAS KESEHATAN KOTA TANGERANG: Universitas Sultan Ageng Tirtayasa; 2018.

6. Ardiyani S, Utaminingsih NS. Analisis determinan financial statement melalui pendekatan fraud triangle. Accounting Analysis Journal. 2015;4(1).

7. Ismail A. Analisis Faktor yang Mempengaruhi Length of Stay Pasien di Instalasi Gawat Darurat Menggunakan Pendekatan Time Frame Guide Emergency Model of Care: Universitas Airlangga; 2018.

8. KeMenKes R. Profil kesehatan Indonesia tahun 2015. Jakarta: Kementerian Kesehatan Republik Indonesia. 2016.

9. Edwards B, Stickney B, Milat A, Campbell D, Thackway S. Building research and evaluation capacity in population health: the NSW Health approach. Health promotion journal of Australia: official journal of Australian Association of Health Promotion Professionals. 2016;27(3):264-7.

10. Umami V, Lydia A, Nainggolan G, Setiati S. Pengembangan Model Prediksi Mortalitas 3 Bulan Pertama pada Pasien Penyakit Ginjal Kronik 
Sumanto, T., Sunarsih, and T. Supodo.

DOI: 10.36566/ijhsrd/Vol3.Iss2/83

https://ijhsrd.com/index.php/ijhsrd

yang Menjalani Hemodialisis. Jurnal

Penyakit Dalam Indonesia. 2015;2(3):170-82.

11. Pakki TR. Pengaruh Kualitas Pelayanan Terhadap Income yang dimoderasi oleh LOS (Length Of Stay) di RS. Paru Dr. HA Rotinsulu Bandung: UNPAS; 2016. 